Балан В.Г. кандидат фізико-математичних наук, доцент, Київський національний університет імені Тараса Шевченка ORCID: https://orcid.org/0000-0002-1577-0636

\title{
НЕЧІТКИЙ СТРАТЕГІЧНИЙ АНАЛІЗ ВНУТРІШНЬОГО СЕРЕДОВИЩА ДИВЕРСИФІКОВАНОГО ПІДПРИЕМСТВА
}

У даній статті пропонується методичний підхід до здійснення стратегічного аналізу внутрішнього середовища диверсифікованого підприємства на основі застосування інструментарію нечітко-множинного моделювання. Для досягнення поставлених иілей у роботі використовуються методи стратегічної діагностики та нечіткі методи багатокритерійного оиінювання Fuzzy AHP та Fuzzy SAW. Розроблена модель містить блок діагностики ідентифікованих складових функціональних сфер діяльності диверсифікованого підприємства та блок оцінювання. Для застосування запропонованої методики розроблено розрахункову схему в Ехсеl, за допомогою якої можна здійснювати трансформачію лінгвістичних оцінок експертів у нечіткі числа, реалізувати обчислення нечітких значень рівня складових внутрішнього середовища підприємства та їх дефазифікацію, а також проводити імітаційне моделювання залежно від корекції міркувань експертів.

Ключові слова: нечітка логіка, нечіткий багатокритерійний аналіз, лінгвістичні змінні, терм-множина, внутрішній стратегічний аудит, стратегічна бізнес-одиниця, Fиzzу AHP, Fuzzy SAW.

Постановка проблеми. На думку відомих фахівців зі стратегічного менеджменту А. А. Томпсона, А. Дж. Стрікленда «грунтовний аналіз положення компанії - необхідна передумова вибору напряму розвитку підприємства в довгостроковій перспективі, постановки цілей і розробки ефективної стратегії» [4, с. 47]. Важливою складовою такого дослідження є стратегічний аналіз його внутрішнього середовища. На важливості участі у даному процесі усього управлінського персоналу та працівників підприємства акцентує увагу професор Wolverhampton Business School Лес Воррал, який підкреслює, що процес проведення внутрішнього аудиту - це можливість для керівників та працівників у всій організації брати участь у визначенні майбутнього фірми. Залучення до процесу може стимулювати та мобілізувати менеджерів та працівників [8]. Дана процедура потребує грунтовних знань складових внутрішнього середовища, його причинно-наслідкових зв'язків і логіко-причинних зв'язків у галузі чи на сегменті ринку та базується, як правило, на експертних міркуваннях й оцінках, які мають «розмитий», нечіткий характер. Це своєю чергою зумовлює необхідність перегляду традиційних методик, недостатньо ефективних із точки зору врахування характеру наявної і прогнозної інформації, та використання нечіткої логіки.

Аналіз останніх досліджень і публікацій. Теоретичним та методичним аспектам стратегічного аналізу підприємств присвячена велика кількість досліджень, зокрема таких відомих зарубіжних та вітчизняних учених, як I. Ансофф [1], Р. Грант [3], П. Дойль, Н. Лейк, А. Томпсон, А. Стрікленд [4], М. Портер, Д. Хассі [5], Ф. Девід [8], Т. Вілін, Д. Хангер, А. Хофман, К. Бемфорд [11], К. Фляйшер, Б. Бенсуссан [6], Л. Довгань, А. Наливайко, Н. Подольчак, 3. Шершньова, А. Шегда та ін. Більшість наукових праць, присвячених темі застосування аналізу внутрішнього середовища, містить приклади проведення стратегічного внутрішнього аудиту підприємств у різних галузях економіки, тобто 3 варіацією напрямів аналізу та його складових відповідно до реляційного простору підприємства, або з прив'язкою їх до різних рівнів стратегічного плану- вання. Слід зазначити, що основними інструментами, які використовуються у процесі досліджень є класичні SWOT-аналіз та SNW-аналіз.

Більш детальний аналіз останніх публікацій та сучасних методичних підходів до стратегічної діагностики внутрішнього середовища підприємства буде розглянуто в основній частині роботи.

Незважаючи на значні здобутки в області вдосконалення інструментарію стратегічного аналізу, існують суттєві прогалини, що стосуються окремих аспектів дослідження й моделювання проблем внутрішнього аудиту диверсифікованих підприємств.

Метою статті $\epsilon$ аналіз сучасних методів стратегічної діагностики внутрішнього середовища диверсифікованого підприємства та його стратегічних бізнес-одиниць, розробка методичного забезпечення поглибленого внутрішнього стратегічного аналізу за визначеними функціональними сферами та їх складовими 3 використанням методів економіко-математичного моделювання на основі теорії нечітких множин.

Виклад основного матеріалу. Дослідження внутрішнього середовища підприємства бажано проводити із залученням зовнішніх організацій - консалтингової фірми, банку тощо. У такий спосіб забезпечується об'єктивність аналізу. Глибина вивчення й формат представлення результатів визначається метою дослідження - від короткого аналізу до «огляду із пристрастю» (Due Diligence) [2].

Одним із основних інструментів, окрім вище зазначених SNW i SWOT-аналізу, є матриця IFE [8], яка дає змогу на основі діагностики сильних та слабких сторін підприємства за допомогою простого адитивного зважування визначити загальну оцінку внутрішнього середовища компанії.

Подібним до матриці IFE є підхід IFAS (Internal factors Analysis Summary) [11]. На думку авторів «таблиця IFAS - це один із способів організації внутрішніх факторів у загальноприйнятих категоріях сильних і слабких сторін, а також аналіз того, наскільки добре керівництво конкретної компанії реагує на ці конкретні фактори з огляду на усвідомлювану їх важливість для компанії» [11, с. 129]. 
Авторами [9] розроблена нечітка модель IFE-аналізу, у якій збільшена варіативність оцінок факторів внутрішнього середовища порівняно 3 класичною схемою та використовуються засоби нечітко-множинної теорії.

У [10] для аналізу внутрішніх корпоративних факторів розроблений методичний підхід FSIF, заснований на нечіткій логіці, у якому автори пропонують оцінювати кожний фактор внутрішнього середовища за значенням функції належності до чотирьох виділених нечітких множин: MJW - Major weakness, MNW Minor weakness, MNS - Minor strength, MJS - Major strength. Стан внутрішнього середовища організації в цілому обчислюється за допомогою адитивного зважування ступенів належності факторів до цих нечітких множин. На думку авторів метод FSIF дає змогу менеджерам бути краще поінформованими про важливі аспекти внутрішнього середовища компанії, що призводить до підвищення ефективності процесу прийняття рішень.

Застосування теорії нечітких множин [13] для вирішення проблем стратегічного аналізу підприємства розширило можливості класичних інструментів і продемонструвало їх ефективність і гнучкість.

Аналіз наукових джерел за темою дослідження дає змогу зробити висновок про необхідність вдоскона- лення існуючого інструментарію внутрішнього аудиту 3 метою більш повного врахування і факторів внутрішнього середовища, і суб'єктивних, неформалізованих, нечітких вхідних даних, думок і суджень експертів. 3 цією метою пропонується розроблений автором методичний підхід на основі теорії нечітких множин, основні етапи якого наведені на рис. 1.

Розглянемо ці етапи детальніше.

Етап 1. Формування робочої групи із $K$ експертів, які мають відповідні компетенції та повноваження (доцільно включити стратегічних аналітиків підприємства та керівників відповідних стратегічних бізнес-одиниць).

Етап 2. Тут необхідно виокремити напрями аналізу внутрішнього середовища (рис. 2).

У роботі [5] пропонується розглядати фактори за шістьма ключовими функціональними сферами організації: фінанси, маркетинг, виробництво, управління людськими ресурсами та ефективність управління, дослідження та розробки та інформаційні системи. Для подальшого аналізу будемо розглядати такі напрями: $D_{1}$ - система управління організацією, $D_{2}-$ кадри, $D_{3}-$ виробництво, $D_{4}-$ маркетинг, $D_{5}-$ фінанси, $D_{6}-$ iнноваційна діяльність.

Етап 3. Нечітке оцінювання важливості визначених напрямів аналізу внутрішнього середовища на основі

Етап 1. Формування експертної групи.

Етап 2. Визначення функціональних сфер (напрямів аналізу) підприємства чи його бізнес-одиниць $D_{1}, D_{2}, \ldots, D_{N}$ (рис. 2).

\begin{tabular}{|c|}
\hline $\begin{array}{l}\text { Етап 3. Застосування Fuzzy } \\
\text { виділ-методу } \\
\text { видених напрямів аналізу внутрішнього середовища } \widetilde{W}_{1}, \widetilde{W}_{2}, \ldots, \widetilde{W}_{N} \cdot\end{array}$ \\
\hline 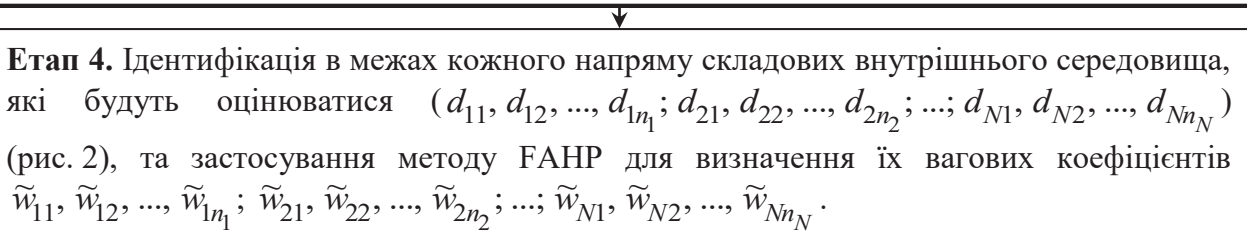 \\
\hline
\end{tabular}

Етап 5. Лінгвістичне оцінювання експертами складових кожного визначеного напряму для кожної стратегічної бізнес-одиниці та застосування шкали переведення якісних оцінок у нечіткі триангулярні числа.

Етап 6. Застосування Fuzzy SAW-методу для визначення інтегральної оцінки внутрішнього середовища за кожним виділеним напрямом аналізу для кожної стратегічної бізнес-одиниці.

Етап 7. Застосування Fuzzy SAW-методу для визначення інтегральної оцінки внутрішнього середовища (за всіма напрямами аналізу) для кожної стратегічної бізнес-одиниці.

Етап 8. Застосування одержаної інформації для підготовки стратегічних рішень (побудова IFE матриці, IE матриці, SNW-аналіз, SWOT-аналіз, матриць портфельного аналізу тощо).

Рисунок 1 - Етапи аналізу та оцінювання
внутрішнього середовища підприсмства

Джерело: розроблено автором 
застосування Fuzzy AНР [7]. Для цього необхідно виконати декілька кроків.

Крок 1. Побудова кожним експертом матриць парних порівнянь напрямів аналізу на основі лінгвістичної шкали (терм-множини), наведеної в табл. 1: $Q^{k}=\left\|q_{i j}^{k}\right\|_{N \times N}$, де $q_{i j}^{k}-$ лінгвістична оцінка $k$-м експертом переважності $i$-го напряму над $j$-м при їх парному порівнянні, $i, j=1,2, \ldots, N ; k=1,2, \ldots, K$.

Лінгвістичні оцінки експертів ( $K=4$ ) напрямів аналізу при їх попарному порівнянні наведені на рис. 3.

Крок 2. Переведення лінгвістичних оцінок у нечіткі числа на основі шкали, наведеної в табл. 1, та відповідних триангулярних нечітких чисел з відповідними функціями належності (рис. 4): $Q^{k} \rightarrow \tilde{F}^{k}$. Таким чином, одержимо нечіткі матриці парних порівнянь визначених напрямів, побудовані кожним експертом: $\tilde{F}^{k}=\left\|\tilde{f}_{i j}^{k}\right\|_{N \times N}=\left\|\left(\alpha_{i j}^{k} ; \beta_{i j}^{k} ; \gamma_{i j}^{k}\right)\right\|_{N \times N}, k=1 ; 2 ; \ldots ; K$.

Крок 3. Обчислення інтегральної нечіткої матриці парних порівнянь стратегічних цілей на основі агрегації нечітких матриць $\tilde{F}^{1}, \tilde{F}^{2} \ldots, \tilde{F}^{K}$ за допомогою наступного співвідношення:

$$
\begin{gathered}
\tilde{F}=\frac{1}{K} \bigoplus_{k=1}^{K} \tilde{f}_{i j}^{k}=\left(\frac{1}{K} \sum_{j=1}^{K} \alpha_{i j}^{k} ; \frac{1}{K} \sum_{j=1}^{K} \beta_{i j}^{k} ; \frac{1}{K} \sum_{j=1}^{K} \gamma_{i j}^{k}\right)= \\
=\left\|\left(\alpha_{i j} ; \beta_{i j} ; \gamma_{i j}\right)\right\|_{N \times N}=\left\|\tilde{f}_{i j}\right\|_{N \times N} .
\end{gathered}
$$

Крок 4. Відповідно до методології FAHP [7] для одержаної матриці $\tilde{F}$ розрахуємо нечіткі числа:

$\tilde{s}_{i}=\left(\sqrt[N]{\alpha_{i 1} \times \ldots \times \alpha_{i N}} ; \sqrt[N]{\beta_{i 1} \times \ldots \times \beta_{i N}} ; \sqrt[N]{\gamma_{i 1} \times \ldots \times \gamma_{i N}}\right)=\left(\alpha_{i} ; \beta_{i} ; \gamma_{i}\right)$,

$$
i=1,2, \ldots, N \text {. }
$$

Далі обчислимо

$$
\begin{gathered}
\tilde{r}=\tilde{s}_{1}(+) \tilde{s}_{2}(+) \ldots(+) \tilde{s}_{N}=\left(\alpha_{1}+\alpha_{2}+\ldots+\alpha_{N} ; \beta_{1}+\beta_{2}+\ldots+\beta_{N} ;\right. \\
\left.\gamma_{1}+\gamma_{2}+\ldots+\gamma_{N}\right)==\left(r_{\alpha} ; r_{\beta} ; r_{\gamma}\right) \text { та } \tilde{r}^{-1}=\left(\frac{1}{r_{\gamma}} ; \frac{1}{r_{\beta}} ; \frac{1}{r_{\alpha}}\right) .
\end{gathered}
$$

Нечіткі коефіцієнти важливості напрямів аналізу одержимо на основі таких співвідношень:

$$
\tilde{V}_{i}=\left(\alpha_{i} ; \beta_{i} ; \gamma_{i}\right)(\times)\left(\frac{1}{r_{\gamma}} ; \frac{1}{r_{\beta}} ; \frac{1}{r_{\alpha}}\right)=\left(\frac{\alpha_{i}}{r_{\gamma}} ; \frac{\beta_{i}}{r_{\beta}} ; \frac{\gamma_{i}}{r_{\alpha}}\right)=\left(V_{i}^{\alpha} ; V_{i}^{\beta} ; V_{i}^{\gamma}\right) .
$$

Ці значення необхідно нормалізувати. Для цього спочатку дефазифікуємо одержані числа, використовуючи метод COA (Centre Of Area) [12] за допомогою наступного співвідношення:

$$
\tilde{V}_{i}^{\text {def }}=\frac{\left(V_{i}^{\gamma}-V_{i}^{\alpha}\right)+\left(V_{i}^{\beta}-V_{i}^{\alpha}\right)}{3}+V_{i}^{\alpha} .
$$

Далі для нормалізації скористаємося такою формулою:

$$
\tilde{W}_{i}=\left(V_{i}^{\alpha} / \sum_{i=1}^{N} \tilde{V}_{i}^{\text {def }} ; V_{i}^{\beta} / \sum_{i=1}^{N} \tilde{V}_{i}^{\text {def }} ; V_{i}^{\gamma} / \sum_{i=1}^{N} \tilde{V}_{i}^{\text {def }}\right)=\left(W_{i}^{\alpha} ; W_{i}^{\beta} ; W_{i}^{\gamma}\right) .
$$

\begin{tabular}{|c|c|c|c|}
\hline $\begin{array}{c}\text { Лінгвістичні терми для визначення відносної } \\
\text { важливості критеріїв (i-го критерію } 3 j \text {-м) }\end{array}$ & Позн. & $\tilde{a}_{i j}$ & $\tilde{a}_{j i}$ \\
\hline Рівноцінні (Equal) & E & $(1 ; 1 ; 1)$ & $(1 ; 1 ; 1)$ \\
\hline Помірна перевага (Moderate) & $\mathrm{M}$ & $(2 ; 3 ; 4)$ & $(1 / 4 ; 1 / 3 ; 1 / 2)$ \\
\hline Сильна перевага (Strong) & $\mathrm{S}$ & $(4 ; 5 ; 6)$ & $(1 / 6 ; 1 / 5 ; 1 / 4)$ \\
\hline Дуже сильна перевага (Very Strong) & VS & $(6 ; 7 ; 8)$ & $(1 / 8 ; 1 / 7 ; 1 / 6)$ \\
\hline Надзвичайно сильна перевага (Extremaly Strong) & ES & $(8 ; 9 ; 9)$ & $(1 / 9 ; 1 / 9 ; 1 / 8)$ \\
\hline \multicolumn{4}{|l|}{ Проміжні (intermediate) нечіткі значення } \\
\hline Дуже слабка перевага (між Е та М) & EiM & $(1 ; 2 ; 3)$ & $(1 / 3 ; 1 / 2 ; 1)$ \\
\hline Перевага (між M та S) & MiS & $(3 ; 4 ; 5)$ & $(1 / 5 ; 1 / 4 ; 1 / 3)$ \\
\hline Сильна перевага (між S та VS) & SiVS & $(5 ; 6 ; 7)$ & $(1 / 7 ; 1 / 6 ; 1 / 5)$ \\
\hline Дуже сильна перевага (між VS та ES) & VSiES & $(7 ; 8 ; 9)$ & $(1 / 9 ; 1 / 8 ; 1 / 7)$ \\
\hline
\end{tabular}

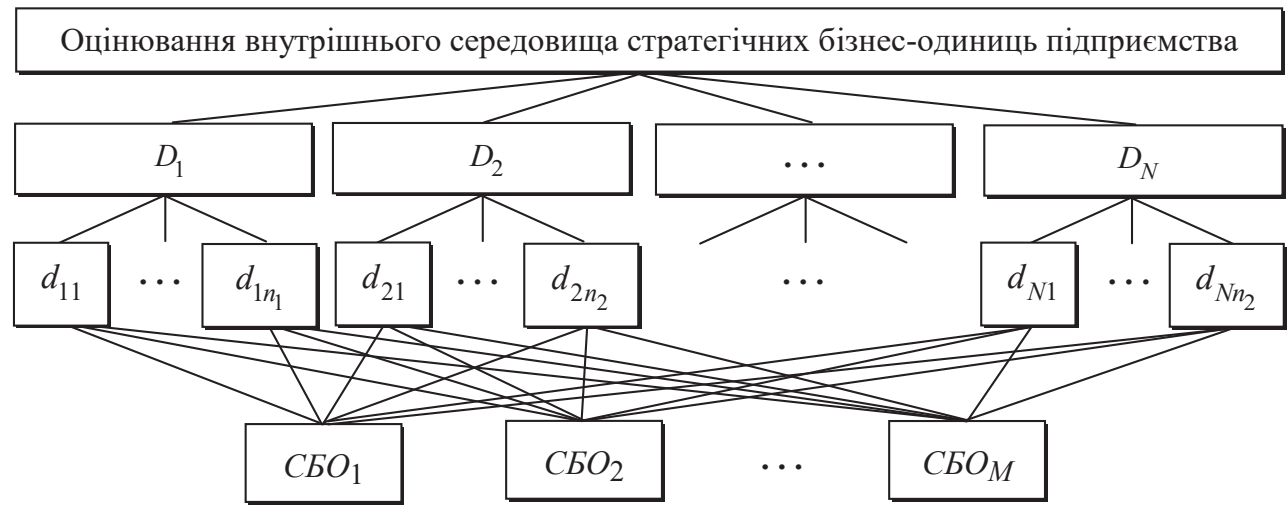

Рисунок 2 - Ієрархія проблеми аналізу та оцінювання внутрішнього середовища підприємства

Джерело: розроблено автором

Таблиця 1 - Шкала переведення лінгвістичних термів у нечіткі триангулярні числа 
Експерт 1

\begin{tabular}{|c|c|c|c|c|c|c|}
\hline$E_{1}$ & $D_{1}$ & $D_{2}$ & $D_{3}$ & $D_{4}$ & $D_{5}$ & $D_{6}$ \\
\hline$D_{1}$ & $\mathrm{E}$ & $\mathrm{EiM}$ & $\mathrm{E}$ & $\mathrm{M}$ & $\mathrm{EiM}$ & $\mathrm{EiM}$ \\
\hline$D_{2}$ & & $\mathrm{E}$ & & $\mathrm{EiM}$ & $\mathrm{E}$ & $\mathrm{E}$ \\
\hline$D_{3}$ & $\mathrm{E}$ & $\mathrm{EiM}$ & $\mathrm{E}$ & $\mathrm{M}$ & $\mathrm{EiM}$ & $\mathrm{EiM}$ \\
\hline$D_{4}$ & & & & $\mathrm{E}$ & & \\
\hline$D_{5}$ & & $\mathrm{E}$ & & $\mathrm{EiM}$ & $\mathrm{E}$ & $\mathrm{E}$ \\
\hline$D_{6}$ & & $\mathrm{E}$ & & $\mathrm{EiM}$ & $\mathrm{E}$ & $\mathrm{E}$ \\
\hline
\end{tabular}

Експерт 3

\begin{tabular}{|c|c|c|c|c|c|c|}
\hline$E_{3}$ & $D_{1}$ & $D_{2}$ & $D_{3}$ & $D_{4}$ & $D_{5}$ & $D_{6}$ \\
\hline$D_{1}$ & $\mathrm{E}$ & $\mathrm{E}$ & $\mathrm{E}$ & $\mathrm{EiM}$ & $\mathrm{M}$ & EiM \\
\hline$D_{2}$ & $\mathrm{E}$ & $\mathrm{E}$ & $\mathrm{E}$ & $\mathrm{EiM}$ & $\mathrm{M}$ & EiM \\
\hline$D_{3}$ & $\mathrm{E}$ & $\mathrm{E}$ & $\mathrm{E}$ & $\mathrm{EiM}$ & $\mathrm{M}$ & $\mathrm{EiM}$ \\
\hline$D_{4}$ & & & & $\mathrm{E}$ & $\mathrm{EiM}$ & $\mathrm{E}$ \\
\hline$D_{5}$ & & & & & $\mathrm{E}$ & \\
\hline$D_{6}$ & & & & $\mathrm{E}$ & $\mathrm{EiM}$ & $\mathrm{E}$ \\
\hline
\end{tabular}

Експерт 2

\begin{tabular}{|c|c|c|c|c|c|c|}
\hline$E_{2}$ & $D_{1}$ & $D_{2}$ & $D_{3}$ & $D_{4}$ & $D_{5}$ & $D_{6}$ \\
\hline$D_{1}$ & $\mathrm{E}$ & $\mathrm{EiM}$ & $\mathrm{EiM}$ & $\mathrm{M}$ & $\mathrm{M}$ & $\mathrm{EiM}$ \\
\hline$D_{2}$ & & $\mathrm{E}$ & $\mathrm{E}$ & $\mathrm{EiM}$ & $\mathrm{EiM}$ & $\mathrm{E}$ \\
\hline$D_{3}$ & & $\mathrm{E}$ & $\mathrm{E}$ & $\mathrm{EiM}$ & $\mathrm{EiM}$ & $\mathrm{E}$ \\
\hline$D_{4}$ & & & & $\mathrm{E}$ & $\mathrm{E}$ & \\
\hline$D_{5}$ & & & & $\mathrm{E}$ & $\mathrm{E}$ & \\
\hline$D_{6}$ & & $\mathrm{E}$ & $\mathrm{E}$ & $\mathrm{EiM}$ & $\mathrm{EiM}$ & $\mathrm{E}$ \\
\hline
\end{tabular}

Експерт 4

\begin{tabular}{|c|c|c|c|c|c|c|}
\hline$E_{4}$ & $D_{1}$ & $D_{2}$ & $D_{3}$ & $D_{4}$ & $D_{5}$ & $D_{6}$ \\
\hline$D_{1}$ & $\mathrm{E}$ & $\mathrm{EiM}$ & $\mathrm{EiM}$ & $\mathrm{M}$ & $\mathrm{EiM}$ & $\mathrm{M}$ \\
\hline$D_{2}$ & & $\mathrm{E}$ & $\mathrm{E}$ & $\mathrm{EiM}$ & $\mathrm{E}$ & $\mathrm{EiM}$ \\
\hline$D_{3}$ & & $\mathrm{E}$ & $\mathrm{E}$ & $\mathrm{EiM}$ & $\mathrm{E}$ & $\mathrm{EiM}$ \\
\hline$D_{4}$ & & & & $\mathrm{E}$ & & $\mathrm{E}$ \\
\hline$D_{5}$ & & $\mathrm{E}$ & $\mathrm{E}$ & $\mathrm{EiM}$ & $\mathrm{E}$ & $\mathrm{EiM}$ \\
\hline$D_{6}$ & & & & $\mathrm{E}$ & & $\mathrm{E}$ \\
\hline
\end{tabular}

Рисунок 3 - Лінгвістичні оцінки напрямів аналізу при їх попарному порівнянні

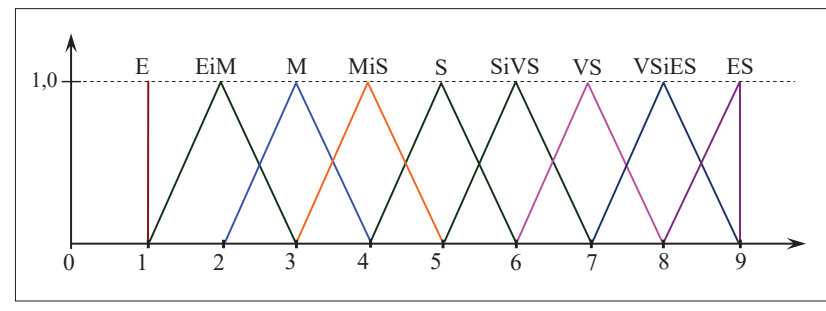

Рисунок 4 - Трикутні функції належності термів при застосуванні FAHP

Етап 4. На цьому етапі в межах кожного напряму необхідно визначити складові внутрішнього середовища, які необхідно проаналізувати та оцінити. Позна- чимо їх таким чином $d_{11}, d_{12}, \ldots, d_{1 n^{2}} ; d_{21}, d_{22}, \ldots, d_{2 n_{2}} ; \ldots$; $d_{N 1}, d_{N 2}, \ldots, d_{N n_{1}}$ (рис. 2, табл. 2).

Далі, використовуючи процедуру методу FAHP аналогічним чином, як це було зроблено на попередньому етапі, розрахуємо вагові коефіцієнти складових внутрішнього середовища за кожним напрямом: $\tilde{w}_{11}, \tilde{w}_{12}, \ldots, \tilde{w}_{1 n_{1}} ; \quad \tilde{w}_{21}, \tilde{w}_{22}, \ldots, \tilde{w}_{2 n_{2}} ; \ldots ; \tilde{w}_{N 1}, \tilde{w}_{N 2}, \ldots, \tilde{w}_{N n_{N}}$, де $\tilde{w}_{i j}=\left(\zeta_{i j} ; \xi_{i j} ; \psi_{i j}\right)$.

Етап 5 присвячений безпосередньому оцінюванню експертами рівня складових кожного визначеного напряму для кожної стратегічної бізнес-одиниці 3 використанням лінгвістичних оцінок на основі терммножини $T=\{$ надзвичайно низький рівень - Extremely Low (EL), дуже низький - Very Low (VL); низький Low (L); середній - Medium (M); високий - High (H);

Таблиця 2 - Складові внутрішнього середовища за напрямами оцінювання

\begin{tabular}{|c|c|}
\hline $\begin{array}{l}\text { Напрями аналізу } \\
\text { та оцінювання }\end{array}$ & Складові внутрішнього середовища \\
\hline $\begin{array}{l}D_{1} \text { - система управління } \\
\text { організацією: }\end{array}$ & $\begin{array}{l}d_{11}-\text { організаційна структура управління; } d_{12}-\text { внутрішня система комунікацій; } d_{13}-\text { загальна } \\
\text { для всієі фірми система контролю (ефективність і використання); } d_{14}-\text { організаційний клімат, } \\
\text { культура; } d_{15}-\text { використання систематизованих процедур і технік у процесі прийняття рішень; } \\
d_{16}-\text { кваліфікація, здібності й інтереси вищого керівництва; } d_{17}-\text { система стратегічного планування; } \\
d_{18}-\text { внутрішньоорганізаційна синергія. }\end{array}$ \\
\hline$D_{2}$ - кадри: & $\begin{array}{l}d_{21}-\text { кадрова політика (наймання, навчання й просування персоналу); } d_{22}-\text { плинність кадрів і } \\
\text { прогули; } d_{23}-\text { управлінський персонал; } d_{24}-\text { виплати працівникам порівняно } 3 \text { аналогічним } \\
\text { показником у конкурентів і в середньому по галузі; } d_{25}-\text { взаємодія менеджерів і працівників; } \\
d_{26}-\text { оцінювання результатів праці й стимулювання. }\end{array}$ \\
\hline$D_{3}$ - виробництво: & $\begin{array}{l}d_{31}-\text { виготовлення продукції; } d_{32}-\text { постачання й ведення складського господарства; } d_{33}-\text { вартість } \\
\text { сировини, іï доступність, відносини } 3 \text { постачальниками; } d_{34}-\text { система контролю запасів, оборот } \\
\text { запасів; } d_{35}-\text { місцезнаходження виробничих приміщень, розташування й використання потужностей; } \\
d_{36}-\text { економія від масштабу виробництва; } d_{37}-\text { технічна ефективність і завантаженість; } d_{38}-\text { ступінь } \\
\text { вертикальної інтеграції; } d_{39}-\text { контроль над процесом виготовлення продукції. } \\
\end{array}$ \\
\hline$D_{4}$ - маркетинг: & \begin{tabular}{|l|}
$d_{41}-$ продуктова стратегія, $d_{42}-$ стратегія ціноутворення; $d_{43}-$ стратегія просування продукції на \\
ринку; $d_{44}-$ вибір ринків збуту й систем розподілу; $d_{44}-$ рекламна діяльність.
\end{tabular} \\
\hline$D_{5}$ - фінанси: & $\begin{array}{l}d_{51}-\text { ліквідність; } d_{52}-\text { обсяги заборгованості; } d_{53}-\text { рентабельність інвестицій; } d_{54}-\text { фінансова } \\
\text { залежність; } d_{55}-\text { стабільність прибутку. }\end{array}$ \\
\hline $\begin{array}{l}D_{6}-\text { інноваційна } \\
\text { діяльність }\end{array}$ & $\begin{array}{l}d_{61}-\text { управління розвитком і дослідженням організації; } d_{62}-\text { інноваційна політика організації; } \\
d_{63}-\text { інноваційний потенціал організації; } d_{64}-\text { дослідження й розробки, інновації; } d_{65}-\text { патенти, } \\
\text { торговельні марки й аналогічні правові форми захисту товару }\end{array}$ \\
\hline
\end{tabular}


дуже високий - Very High (VH), надзвичайно високий - Extremely High (EH)\}. Семантика термів задається нечіткими числами на інтервалі $[0 ; 6]$ з відповідними функціями належності (рис. 5) - EnS: $(0 ; 0 ; 1)$; VL: $(0 ; 1 ; 2)$; $:(1 ; 2 ; 3)$; M: $(2 ; 3 ; 4) ; \mathrm{H}:(3 ; 4 ; 5)$; VH: $(4 ; 5 ; 6)$; ЕН: $(5 ; 6 ; 6)$.

Відзначимо, що дані оцінки можна використовувати як результати поглибленого SNW-аналізу внутрішнього середовища, для застосування в кореляційній матриці SWOT-аналізу, оскільки оцінки EL, VL та L характеризують слабкі сторони підприємства (з градацією слабкості), Н, VH та ЕН - сильні сторони (з градацією сили), М - нейтральні сторони.

Результати оцінювання експертами рівня складових внутрішнього середовища у лінгвістичній формі наведені в табл. 3 (через великий обсяг наведено фрагмент цих оцінок).

Використовуючи представлення лінгвістичних оцінок за допомогою нечітких чисел у триангулярній формі (рис. 5), можна отримати нечіткі матриці $\tilde{R}^{p k}=\left\|\tilde{r}_{i j}^{p k}\right\|=\left\|\left(a_{i j}^{p k} ; b_{i j}^{p k} ; c_{i j}^{p k}\right)\right\|, \quad k=1,2, \ldots, K, \quad i=1,2, \ldots, N$, $j=1,2, \ldots, n_{i}, p=1,2, \ldots, M, M-$ кількість СБО підприємства (табл. 4).

Агрегуємо нечіткі оцінки експертів, використовуючи формулу аналогічну (1):

$$
\tilde{R}^{p}=\frac{1}{K} \bigoplus_{k=1}^{K} \tilde{r}_{i j}^{p k}=\left(\frac{1}{K} \sum_{j=1}^{K} a_{i j}^{p k} ; \frac{1}{K} \sum_{j=1}^{K} b_{i j}^{p k} ; \frac{1}{K} \sum_{j=1}^{K} c_{i j}^{p k}\right)=\left\|\left(a_{i j}^{p} ; b_{i j}^{p} ; b_{i j}^{p}\right)\right\| .
$$

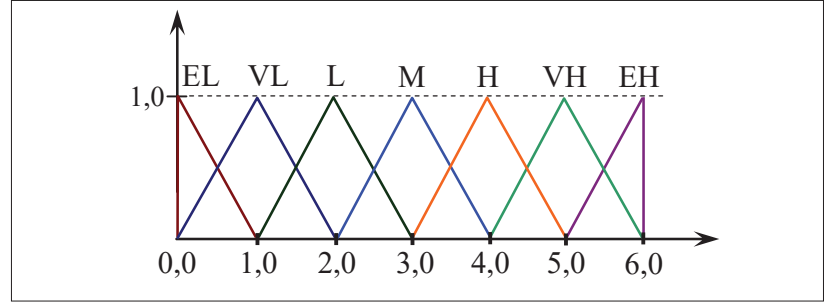

Рисунок 5 - Трикутні функції належності термів оцінювання складових внутрішнього середовища підприсмства

Таким чином, одержимо матрицю оцінок складових внутрішнього середовища диверсифікованого підприємства $\tilde{R}^{p}=\left\|\tilde{r}_{i j}^{p}\right\|$ (табл. 5).

Етап 6. Для визначення інтегральної оцінки внутрішнього середовища за кожним виділеним напрямом аналізу для кожної $p$-ї стратегічної бізнес-одиниці скористаємося Fuzzy SAW-методом:

$$
\tilde{R}^{p}\left(D_{i}\right)=\bigoplus_{j=1}^{n_{i}} \tilde{w}_{i j}(\times) \tilde{r}_{i j}^{p}=
$$

$$
=\left(\sum_{j=1}^{n_{i}} \varsigma_{i j} \times a_{i j}^{p} ; \sum_{j=1}^{n_{i}} \xi_{i j} \times b_{i j}^{p} ; \sum_{j=1}^{n_{i}} \psi_{i j} \times c_{i j}^{p}\right)=\left(A_{i}^{p} ; B_{i}^{p} ; C_{i}^{p}\right) .
$$

Далі необхідно дефазифікувати нечіткі значення $\tilde{R}^{p}\left(D_{i}\right)=\left(A_{i}^{p} ; B_{i}^{p} ; C_{i}^{p}\right)$ за допомогою методу CoА: $\left(\tilde{R}^{p}\left(D_{i}\right)\right)^{\text {def }}=\frac{\left(C_{i}^{p}-A_{i}^{p}\right)+\left(B_{i}^{p}-A_{i}^{p}\right)}{3}+A_{i}^{p}$.

\begin{tabular}{|c|c|c|c|c|c|c|c|c|c|c|c|c|c|}
\hline & & \multicolumn{4}{|c|}{$C Б O_{1}$} & \multicolumn{4}{|c|}{$\mathrm{CSO}_{2}$} & \multicolumn{4}{|c|}{$\mathrm{CSO}_{3}$} \\
\hline & & $E_{1}$ & $E_{2}$ & $E_{3}$ & $E_{4}$ & $E_{1}$ & $E_{2}$ & $E_{3}$ & $E_{4}$ & $E_{1}$ & $E_{2}$ & $E_{3}$ & $E_{4}$ \\
\hline \multirow{8}{*}{$D_{1}$} & $d_{11}$ & $\mathrm{H}$ & $\mathrm{VH}$ & $\mathrm{M}$ & $\mathrm{H}$ & $\mathrm{H}$ & $\mathrm{M}$ & $\mathrm{M}$ & $\mathrm{M}$ & $\mathrm{M}$ & $\mathrm{M}$ & $\mathrm{L}$ & $\mathrm{L}$ \\
\hline & $d_{12}$ & $\mathrm{M}$ & $\mathrm{H}$ & $\mathrm{H}$ & $\mathrm{M}$ & $\mathrm{M}$ & $\mathrm{M}$ & $\mathrm{L}$ & $\mathrm{M}$ & $\mathrm{H}$ & $\mathrm{M}$ & $\mathrm{M}$ & $\mathrm{L}$ \\
\hline & $d_{13}$ & $\mathrm{~L}$ & $\mathrm{M}$ & $\mathrm{L}$ & $\mathrm{L}$ & $\mathrm{H}$ & $\mathrm{H}$ & $\mathrm{VH}$ & $\mathrm{H}$ & $\mathrm{L}$ & $\mathrm{L}$ & $\mathrm{VL}$ & $\mathrm{L}$ \\
\hline & $d_{14}$ & $\mathrm{H}$ & $\mathrm{H}$ & $\mathrm{M}$ & $\mathrm{M}$ & VH & VH & $\mathrm{H}$ & $\mathrm{VH}$ & $\mathrm{L}$ & $\mathrm{M}$ & VL & $\mathrm{L}$ \\
\hline & $d_{15}$ & $\mathrm{~L}$ & $\mathrm{M}$ & $\mathrm{L}$ & VL & $\mathrm{M}$ & $\mathrm{M}$ & $\mathrm{H}$ & $\mathrm{M}$ & $\mathrm{L}$ & $\mathrm{VL}$ & EL & $\mathrm{L}$ \\
\hline & $d_{16}$ & $\mathrm{H}$ & $\mathrm{M}$ & $\mathrm{H}$ & $\mathrm{H}$ & $\mathrm{H}$ & $\mathrm{VH}$ & $\mathrm{H}$ & $\mathrm{H}$ & $\mathrm{M}$ & $\mathrm{M}$ & $\mathrm{L}$ & $\mathrm{L}$ \\
\hline & $d_{17}$ & VL & EL & $\mathrm{VL}$ & $\mathrm{L}$ & $\mathrm{M}$ & $\mathrm{L}$ & $\mathrm{L}$ & $\mathrm{M}$ & $\mathrm{L}$ & $\mathrm{VL}$ & $\mathrm{L}$ & $\mathrm{L}$ \\
\hline & $d_{18}$ & $\mathrm{~L}$ & EL & $\mathrm{L}$ & VL & $\mathrm{M}$ & $\mathrm{M}$ & $\mathrm{L}$ & $\mathrm{L}$ & $\mathrm{VL}$ & EL & EL & VL \\
\hline$\ldots$ & $\ldots$ & $\ldots$ & $\ldots$ & $\ldots$ & $\ldots$ & $\ldots$ & $\ldots$ & $\ldots$ & $\ldots$ & $\ldots$ & $\ldots$ & $\ldots$ & $\ldots$ \\
\hline
\end{tabular}

Таблиця 3 - Фрагмент матриць лінгвістичного оцінювання експертами складових внутрішнього середовища диверсифікованого підприсмства

\begin{tabular}{|c|c|c|c|c|c|c|c|c|c|c|c|c|c|}
\hline & & \multicolumn{4}{|c|}{$C Б O_{1}$} & \multicolumn{4}{|c|}{$\mathrm{CSO}_{2}$} & \multicolumn{4}{|c|}{$\mathrm{CDO}_{3}$} \\
\hline & & $E_{1}$ & $E_{2}$ & $E_{3}$ & $E_{4}$ & $E_{1}$ & $E_{2}$ & $E_{3}$ & $E_{4}$ & $E_{1}$ & $E_{2}$ & $E_{3}$ & $E_{4}$ \\
\hline \multirow{8}{*}{$D_{1}$} & $d_{11}$ & $(3 ; 4 ; 5)$ & $(4 ; 5 ; 6)$ & $(2 ; 3 ; 4)$ & $(3 ; 4 ; 5)$ & $(3 ; 4 ; 5)$ & $(2 ; 3 ; 4)$ & $(2 ; 3 ; 4)$ & $(2 ; 3 ; 4)$ & $(2 ; 3 ; 4)$ & $(2 ; 3 ; 4)$ & $(1 ; 2 ; 3)$ & $(1 ; 2 ; 3)$ \\
\hline & $d_{12}$ & $(2 ; 3 ; 4)$ & $(3 ; 4 ; 5)$ & $(3 ; 4 ; 5)$ & $(2 ; 3 ; 4)$ & $(2 ; 3 ; 4)$ & $(2 ; 3 ; 4)$ & $(1 ; 2 ; 3)$ & $(2 ; 3 ; 4)$ & $(3 ; 4 ; 5)$ & $(2 ; 3 ; 4)$ & $(2 ; 3 ; 4)$ & $(1 ; 2 ; 3)$ \\
\hline & $d_{13}$ & $(1 ; 2 ; 3)$ & $(2 ; 3 ; 4)$ & $(1 ; 2 ; 3)$ & $(1 ; 2 ; 3)$ & $(3 ; 4 ; 5)$ & $(3 ; 4 ; 5)$ & $(4 ; 5 ; 6)$ & $(3 ; 4 ; 5)$ & $(1 ; 2 ; 3)$ & $(1 ; 2 ; 3)$ & $(0 ; 1 ; 2)$ & $(1 ; 2 ; 3)$ \\
\hline & $d_{14}$ & $(3 ; 4 ; 5)$ & $(3 ; 4 ; 5)$ & $(2 ; 3 ; 4)$ & $(2 ; 3 ; 4)$ & $(4 ; 5 ; 6)$ & $(4 ; 5 ; 6)$ & $(3 ; 4 ; 5)$ & $(4 ; 5 ; 6)$ & $(1 ; 2 ; 3)$ & $(2 ; 3 ; 4)$ & $(0 ; 1 ; 2)$ & $(1 ; 2 ; 3)$ \\
\hline & $d_{15}$ & $(1 ; 2 ; 3)$ & $(2 ; 3 ; 4)$ & $(1 ; 2 ; 3)$ & $(0 ; 1 ; 2)$ & $(2 ; 3 ; 4)$ & $(2 ; 3 ; 4)$ & $(3 ; 4 ; 5)$ & $(2 ; 3 ; 4)$ & $(1 ; 2 ; 3)$ & $(0 ; 1 ; 2)$ & $(0 ; 0 ; 1)$ & $(1 ; 2 ; 3)$ \\
\hline & $d_{16}$ & $(3 ; 4 ; 5)$ & $(2 ; 3 ; 4)$ & $(3 ; 4 ; 5)$ & $(3 ; 4 ; 5)$ & $(3 ; 4 ; 5)$ & $(4 ; 5 ; 6)$ & $(3 ; 4 ; 5)$ & $(3 ; 4 ; 5)$ & $(2 ; 3 ; 4)$ & $(2 ; 3 ; 4)$ & $(1 ; 2 ; 3)$ & $(1 ; 2 ; 3)$ \\
\hline & $d_{17}$ & $(0 ; 1 ; 2)$ & $(0 ; 0 ; 1)$ & $(0 ; 1 ; 2)$ & $(1 ; 2 ; 3)$ & $(2 ; 3 ; 4)$ & $(1 ; 2 ; 3)$ & $(1 ; 2 ; 3)$ & $(2 ; 3 ; 4)$ & $(1 ; 2 ; 3)$ & $(0 ; 1 ; 2)$ & $(1 ; 2 ; 3)$ & $(1 ; 2 ; 3)$ \\
\hline & $d_{18}$ & $(1 ; 2 ; 3)$ & $(0 ; 0 ; 1)$ & $(1 ; 2 ; 3)$ & $(0 ; 1 ; 2)$ & $(2 ; 3 ; 4)$ & $(2 ; 3 ; 4)$ & $(1 ; 2 ; 3)$ & $(1 ; 2 ; 3)$ & $(0 ; 1 ; 2)$ & $(0 ; 0 ; 1)$ & $(0 ; 0 ; 1)$ & $(0 ; 1 ; 2)$ \\
\hline & $\ldots$ & $\ldots$ & $\ldots$ & $\ldots$ & $\ldots$ & $\ldots$ & $\ldots$ & & $\ldots$ & $\ldots$ & 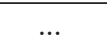 & 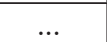 & \\
\hline
\end{tabular}

Таблиця 4 - Фрагмент нечітких матриць оцінювання експертами складових внутрішнього середовища диверсифікованого підприємства 
Таблиця 5 - Фрагмент агрегованої нечіткої матриці оцінювання складових внутрішнього середовища диверсифікованого підприємства

\begin{tabular}{|c|c|c|c|c|}
\hline \multicolumn{2}{|c|}{} & $C Б O_{1}$ & $C Б O_{2}$ & $C_{3}$ \\
\hline \multirow{5}{*}{} & $d_{11}$ & $(3 ; 4 ; 5)$ & $(2,25 ; 3,25 ; 4,25)$ & $(1,5 ; 2,5 ; 3,5)$ \\
\cline { 2 - 5 } & $d_{12}$ & $(2,5 ; 3,5 ; 4,5)$ & $(1,75 ; 2,75 ; 3,75)$ & $(2 ; 3 ; 4)$ \\
\cline { 2 - 5 } & $d_{13}$ & $(1,25 ; 2,25 ; 3,25)$ & $(3,25 ; 4,25 ; 5,25)$ & $(1 ; 2 ; 3)$ \\
\cline { 2 - 5 } & $d_{14}$ & $(2,5 ; 3,5 ; 4,5)$ & $(3,75 ; 4,75 ; 5,75)$ & $(0,5 ; 1,25 ; 2,25)$ \\
\cline { 2 - 5 } & $d_{15}$ & $(1 ; 2 ; 3)$ & $(2,25 ; 3,25 ; 4,25)$ & $(1,5 ; 2,5 ; 3,5)$ \\
\cline { 2 - 5 } & $d_{16}$ & $(2,75 ; 3,75 ; 4,75)$ & $(3,25 ; 4,25 ; 5,25)$ & $(0,75 ; 1,75 ; 2,75)$ \\
\cline { 2 - 5 } & $d_{17}$ & $(0,25 ; 1 ; 2)$ & $(1,5 ; 2,5 ; 3,5)$ & $\ldots$ \\
\cline { 2 - 5 } & $d_{18}$ & $(0,5 ; 1,25 ; 2,25)$ & $\ldots$ & $\ldots, 5 ; 1,5)$ \\
\hline$\ldots$ & $\ldots$ & $\ldots$ & & \\
\hline
\end{tabular}

Одержані значення можна використовувати:

- для компаративного аналізу стратегічних бізнесодиниць підприємства за визначеними напрямами;

- для абсолютного оцінювання кожної СБО за цими напрямами за 6-ти бальною шкалою.

Етап 7. Застосування Fuzzy SAW-методу для визначення інтегральної оцінки внутрішнього середовища (за всіма напрямами аналізу) для кожної стратегічної бізнес-одиниці.

$$
\begin{gathered}
\tilde{R}^{p}=\bigoplus_{i=1}^{N} \tilde{W}_{i}(\times) \tilde{R}^{p}\left(D_{i}\right)= \\
=\left(\sum_{i=1}^{N} W_{i}^{\alpha} \times A_{i}^{p} ; \sum_{i=1}^{N} ; W_{i}^{\beta} \times B_{i}^{p} ; \sum_{i=1}^{N} ; W_{i}^{\gamma} \times C_{i}^{p}\right)=\left(A^{p} ; B^{p} ; C^{p}\right) .
\end{gathered}
$$

Як і на попередньому етапі дефазифікуємо одержані значення:

$$
\left(\tilde{R}^{p}\right)^{d e f}=\frac{\left(C^{p}-A^{p}\right)+\left(B^{p}-A^{p}\right)}{3}+A^{p} .
$$

Якщо дана оцінка є нижчою 3 , то це вказує на те, що дана СБО має суттєві внутрішні проблеми та слабкості, а якщо більше 3, то має потенційні сильні сторони.

Етап 8. Одержана інформація дає змогу вищому керівництву стратегічних бізнес-одиниць і всього підприємства усвідомити проблемні моменти за визначеними напрямами аналізу, розширює можливості традиційних методів IFEM, SNW-аналізу, є важливим інструментом для підготовки стратегічних рішень.

Для застосування запропонованої методики було розроблено розрахункову схему в Excel, за допомогою якої можна здійснювати трансформацію лінг- вістичних оцінок експертів у нечіткі числа, записані в триангулярній формі 3 відповідними функціями належності, реалізувати обчислення нечітких значень рівня складових внутрішнього середовища підприємства (його СБО) та їх дефазифікацію, а також провести імітаційне моделювання залежно від корекції міркувань експертів.

Висновки. Розроблений методичний підхід до здійснення діагностики внутрішнього середовища диверсифікованого підприємства 3 використанням нечіткого економіко-математичного моделювання, зокрема нечітких методів FAHP та FSAW, дає змогу більш комплексно і гнучко підійти до процесу внутрішнього аудиту за рахунок більш повного врахування і факторів внутрішнього середовища, і суб'єктивних, неформалізованих, нечітких вхідних даних, думок і суджень експертів.

Подальші дослідження за даною темою можуть бути спрямовані на:

- адаптацію даної методики, зокрема напрямів оцінювання (складових внутрішнього середовища) відповідно до потреб аналізу та до реляційного простору підприємства (його стратегічних бізнес-одиниць);

- розробку фреймворку аналізу та оцінювання внутрішнього середовища 3 використанням спеціалізованих додатків, які реалізують можливості нечіткого моделювання, наприклад, у пакеті Fuzzy Logic Toolbox обчислювальної системи Matlab, у Fuzzy Control Design Toolbox, fuzzyTECH тощо;

- розробки і включення процедури попереднього узгодження міркувань експертів на усіх етапах процедури оцінювання.

\section{Список використаних джерел:}

1. Ансофф И. Стратегическое управление. М.: Экономика, 1989. 519 с.

2. Балан В.Г. Стратегічне управління. Практикум. К.: Наукова столиця. 2018. 524 с.

3. Грант Р.М. Современный стратегический анализ: 5-е изд. СПб: Питер, 2008. 560 с.

4. Томпсон А. А., Стрикленд А. Дж. Стратегический менеджмент: концепции и ситуации для анализа, 12-е издание: Пер. с англ. Москва : Издательский дом «Вильямс», 2006. 928 с.

5. Хасси Д. Стратегия и планирование. СПб.: Питер, 2008. 560 с.

6. Фляйшер К., Бенсуссан Б. Стратегический и конкурентный анализ. Методы и средства конкурентного анализа в бизнесе. М.: БИНОМ. Лаборатория знаний, 2005. 541 с.

7. Chang D.Y. Applications of the extent analysis method on fuzzy AHP. European Journal of Operational Research. 1996. Vol. 95 (3). P. 649-655.

8. David F. Strategic Management: Concepts and Cases, 11th Edition. Prentice Hall, 2006. 657 p.

9. Mohammadi A., Mohammadi Ab., Zarifpayam S.V., Mohammadi M. Presentation of Fuzzy Models of EFE, IFE and QSPM. Australian Journal of Basic and Applied Sciences. 2011. Vol. 5(12). P. 1173-1179.

10. Pešić A., Pešić D., Tepavčević A. A New Strategic Tool for Internal Audit of the Company Based on Fuzzy Logic. ComSIS. 2012. Vol. 9. №. 2. P. 653-666. 
11. Wheelen T.L., Hunger D.L. Hoffman A. N., Bamford C.E. Strategic Management and Business Policy. Globalization, innovation, and sustainability. Pearson Education Limited, 2018. 851 p.

12. Wu H. Y., Tzeng G. H., Chen Y. H. A fuzzy MCDM approach for evaluating banking performance based on Balanced Scorecard. Expert Systems with Applications 2009. Vol. 36. P. 10135-10147.

13. Zadeh L.A. Fuzzy Sets as a Basis for a Theory of Possibility. Fuzzy Sets and Systems. 1978. Vol. 1. № 1. P. 89-100.

\title{
References:
}

1. Ansoff I. (1989) Strategicheskoe upravlenie [Strategic management]. Moscow : Jekonomika, 519 p. (in Russian)

2. Balan V.H. (2018) Stratehichne upravlinnia. Praktykum [Strategic management. Workshop]. 2-he vyd., pererob. i dop. Kyiv: Naukova stolytsia, 524 p. (in Ukrainian)

3. Grant R.M. (2008) Sovremennyj strategicheskij analiz: 5-e izd. [Contemporary strategy analysis: fifth edition]. SPb: Piter, 560 p. (in Russian)

4. Tompson A. A., Striklend A. Dzh. (2006) Strategicheskij menedzhment: koncepcii i situacii dlja analiza [Strategic management: concepts and cases]. Moscow : Izdatel'skij dom «Vil'jams», 928 p. (in Russian)

5. Hassi D. (2008) Strategija i planirovanie [Strategy and planning]. SPb.: Piter, 560 p. (in Russian)

6. Fljajsher K., Bensussan B. (2005) Strategicheskij i konkurentnyj analiz. Metody i sredstva konkurentnogo analiza v biznese [Strategic and Competitive Analysis. Methods and Techniques for Analyzing Business Competition]. Moscow : BINOM. Laboratorija znanij, 541 p. (in Russian)

7. Chang D.Y. (1996) Applications of the extent analysis method on fuzzy AHP. European Journal of Operational Research., vol. 95 (3), pp. 649-655.

8. David F. (2006) Strategic Management: Concepts and Cases, 11th Edition. Prentice Hall, 657 p.

9. Mohammadi A., Mohammadi Ab., Zarifpayam S.V., Mohammadi M. (2011). Presentation of Fuzzy Models of EFE, IFE and QSPM. Australian Journal of Basic and Applied Sciences, vol. 5(12), pp. 1173-1179.

10. Pešić A., Pešić D., Tepavčević A. A New Strategic Tool for Internal Audit of the Company Based on Fuzzy Logic. ComSIS, 2012, vol. 9, no. 2, pp. 653-666.

11. Wheelen T.L., Hunger D.L. Hoffman A. N., Bamford C.E. (2018) Strategic Management and Business Policy. Globalization, innovation, and sustainability. Pearson Education Limited, $851 \mathrm{p}$.

12. Wu H. Y., Tzeng G. H., Chen Y. H. (2009) A fuzzy MCDM approach for evaluating banking performance based on Balanced Scorecard. Expert Systems with Applications, vol. 36, pp. 10135-10147.

13. Zadeh L.A. (1978). Fuzzy Sets as a Basis for a Theory of Possibility. Fuzzy Sets and Systems, vol. 1, no 1, pp. 89-100.

\author{
Balan Valeriy
}

Taras Shevchenko National University of Kyiv

\section{FUZZY STRATEGIC ANALYSIS OF THE DIVERSIFIED ENTERPRISE INTERNAL ENVIRONMENT}

This article proposes a methodological approach for strategic analysis of the internal environment of a diversified enterprise based on the use of fuzzy-multiple modeling tools. To achieve the set goals the strategic diagnostics methods and fuzzy methods of multicriteria evaluation are used in the work, in particular the hierarchies method analysis in fuzzy formulation (Fuzzy AHP) and Fuzzy SAW. Peculiarities of application of classical internal audit tools (IFEM method, SNW-analysis, IFAS method) and modern models based on FIFEM, FSIF fuzzy logic are analyzed. The developed model contains a diagnostics block of the identified components of functional spheres of the diversified enterprise activity (with application of linguistic estimations on the certain term-set with the subsequent translation into fuzzy numbers in triangulative representation) and the estimation block (meanwhile Fuzzy AHP method is used to calculate the importance of the analyzed areas of activity and their components, and the Fuzzy SAW method - to determine fuzzy integrated assessments of the enterprise internal environment (or its strategic business units - SBU) by functional areas and in general. For defuzzification of fuzzy numbers the method of COA is used (Center Of Area). The information received can be used for comparative analysis of enterprise strategic business units in certain areas, for absolute assessment of the internal environment of each SBU in these areas on a 6-point scale. Thus, this methodological approach allows senior management of strategic business units and the whole enterprise to understand the problems in each functional area, expands the capabilities of strategic diagnosis traditional methods, and is an important tool for preparing strategic decisions using the correlation matrix SWOT-analysis and other methods of portfolio analysis (GE-McKinsey, Shell DPM, SPACE-analysis etc). To apply the proposed method a calculation scheme was developed in Excel, which can be used to transform linguistic estimates of experts into fuzzy numbers written in triangular form with the corresponding membership functions, to calculate fuzzy values of the enterprise internal environment (its $S B U)$ and their defuzzification, as well as to conduct simulation depending on the correction of expert opinions.

Key words: fuzzy logic, fuzzy multicriteria analysis, linguistic variables, term-set, internal strategic audit, strategic business unit, Fuzzy AHP, Fuzzy SAW.

JEL classification: $\mathrm{C} 52, \mathrm{O} 12$ 